\title{
Assessing the Provenance of Poverty Point Copper through LA-ICP-MS Compositional Analysis
}

\author{
Mark A. Hill \\ Department of Anthropology \\ Ball State University \\ Diana M. Greenlee \\ School of Sciences \\ University of Louisiana at Monroe \\ Hector Neff \\ Department of Anthropology \\ California State University-Long Beach
}

May 2015

NOT FOR CITATION WITHOUT PERMISSION OF THE AUTHORS

${ }^{*}$ Corresponding Author 


\begin{abstract}
The Poverty Point site is the largest and most complex Archaic period earthwork site in eastern North America and the type site of the Poverty Point culture. Poverty Point holds a prominent position in eastern North American prehistory in part due to the extensive exchange system - the first of such scale-that brought exotic materials to this site from the Appalachians, Ohio Valley, and Upper Mississippi Valley. Among these exotic materials, copper was introduced into the Poverty Point exchange system from sources often posited to reside in the upper Great Lakes region, an idea reinforced by the identification of Upper Mississippi Valley sources for galena found at the site. This study tests such an assumption by using laser ablation inductively-coupled plasma mass spectrometry (LA-ICP-MS) analysis of six copper artifacts from the Poverty Point site and comparing the results to source samples from the Lake Superior region, central and southern Appalachian Mountains, and Canadian Maritimes. Results indicate that these copper artifacts most likely originated in the eastern sources of the Maritimes or Appalachian Mountains, rather than the Lake Superior region as long proposed.
\end{abstract}

\title{
1. Introduction
}

The Poverty Point site (16WC5), located in northeastern Louisiana, is the largest and most complex Archaic earthwork site in eastern North America and the main site of the Poverty Point culture (Ford and Webb 1956; Gibson 2010:77-96; Webb 1968, 1982). Monumental earthen architecture, post circles, and extensive long-distance raw material acquisition suggest that Poverty Point holds a position of some importance in the social developments of eastern North America.

Long distance exchange, on a scale not seen previously, is one of the salient features of the Poverty Point culture. Indeed, as Gibson (2001:171) states "...exchange was one of the defining aspects of Poverty Point culture and one of the most important drivers of its unique development." Exotic materials, including Burlington chert, "Northern Gray" chert (a catchall term encompassing Cobden, Wyandotte, Dover, and other cherts of the Ohio and Mississippi valleys), novaculite, quartz crystals, fluorite, steatite, sandstone, galena, and copper, were transported to Poverty Point, an estimated 71 metric tons in all, over nearly 6 centuries after 3700 BP (Gibson 1994, 1999, 2007; Smith 1991; Walthall et al. 1982; Webb 1982; Yates 2009). The sources for these materials are found throughout the central and southeastern United States, especially along the Mississippi River and its primary tributaries as shown in Figure 1 (Gibson 1994:130, 1999:57).

Among these exotic materials, native copper is featured in the form of beads, pendants, awls, thin sheets, nuggets, and at least one copper plummet (Bell 1956; Webb 1982). While some of the geological sources of exotic materials found at Poverty Point have been confirmed through the use of elemental composition studies (e.g., Ghosh 2008; Greenlee et al. 2014; Walthall et al. 1982; Wisseman et al. 2010; Yates 2009), Poverty Point copper has so far eluded attempts to identify its provenance (Lasley 1983). It has been widely assumed to originate in the deposits of the upper Great Lakes, an 


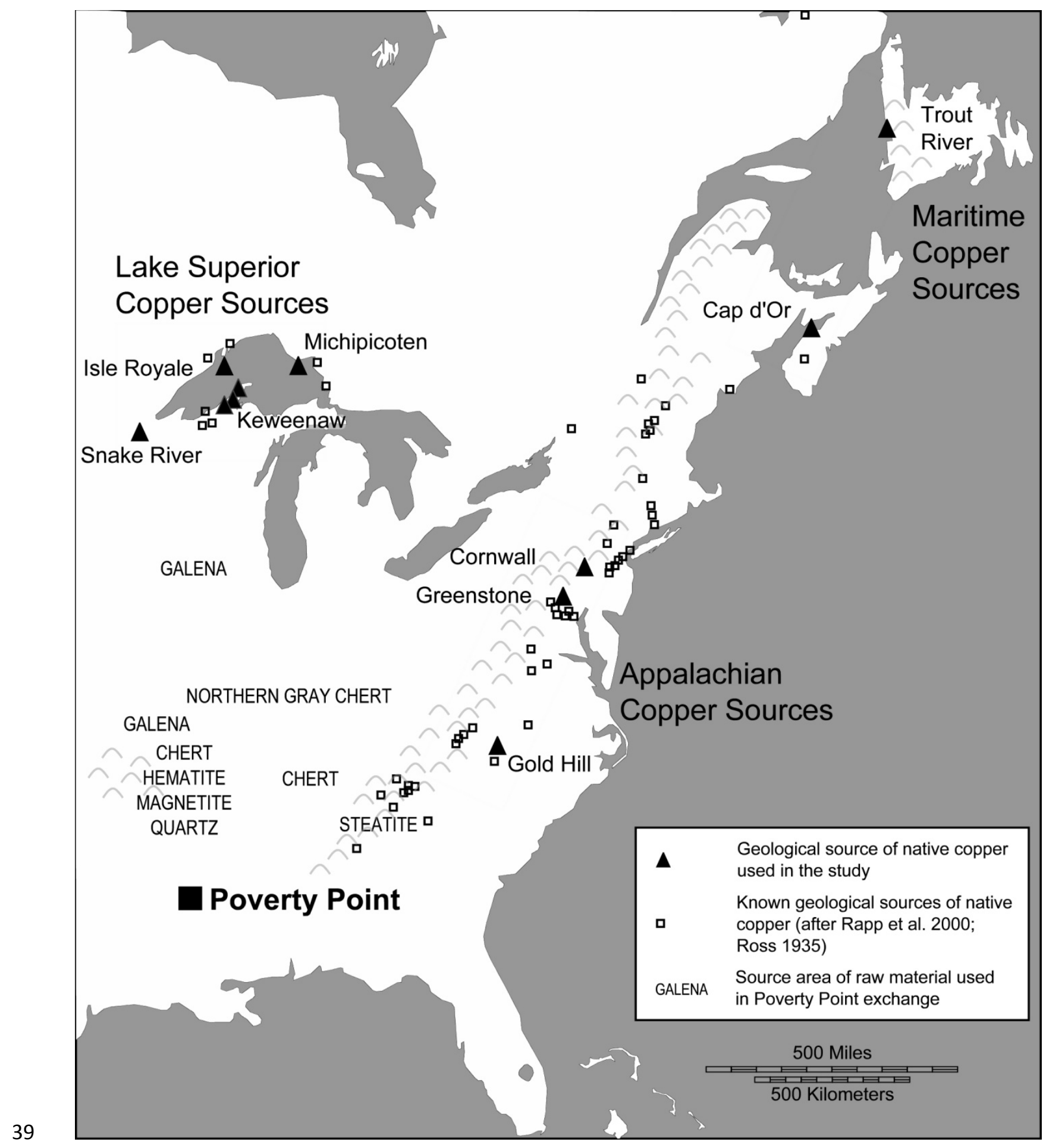

40 Figure 1. Location of Poverty Point, raw material source regions, and copper sources discussed in the 41 text. 
assumption strengthened by research which has determined that some of the galena found at Poverty Point originates from sources in the Upper Mississippi Valley (Ghosh 2008; Walthall et al. 1982).

While the deposits around Lake Superior are best known, other sources of native copper exist in eastern North America. These native copper deposits are found in Newfoundland, Nova Scotia, and the Appalachians as far south as Georgia and northern Alabama (Rapp et al. 2000). Does Poverty Point copper actually derive from sources in the Great Lakes as assumed, or could it derive in whole or in part from these other sources instead?

Research into the provenance of Poverty Point copper has so far been unable to answer this question. Only one previous study, using particle-induced x-ray emission, examined copper from Poverty Point; it produced inconclusive results (Lasley 1983). However, in a much wider study that did not include Poverty Point materials, Goad (1980) determined that some of the Archaic-aged copper in the southeast was most consistent with sources in the Appalachians.

Thus two pathways appear as possible routes for the introduction of copper to Poverty Point. One, from the Great Lakes down the Mississippi Valley, partially following the route used to import galena (Walthall et al. 1982), or another across the southeast from the Appalachians, potentially following the route used to transport steatite vessels (Truncer 2004; Yates 2009). In this study, we address the issue of Poverty Point copper provenance by using Laser Ablation Inductively Coupled Plasma Mass Spectrometry (LA-ICP-MS) to examine the compositional profiles of six copper specimens collected from Poverty Point and to compare them with established compositional profiles of North American native copper sources.

\subsection{Poverty Point in North American Prehistory}

The acquisition of exotic raw materials is only one of Poverty Point's significant characteristics. Indeed, the size, scale, and complexity of the earthworks are exceptional for their time (ca. 3700-3100 BP; Connolly 2006) and the design is unique in the world. The most visible feature of the site is the enormous Mound $A$, the largest of five mounds that comprise the original Late Archaic earthworks (a sixth mound was added some 1700-2000 years later, during the Late Woodland period [Greenlee 2011]). Six concentric, semi-elliptical earthen ridges surround a 17.4 ha flat, interior plaza; the plaza contains evidence for circles of large wooden posts (Greenlee 2009; Hargrave et al. 2010). The ridges served as the residential space for what was likely a substantial, sedentary, permanent population. Most remarkably, the people of Poverty Point were hunter-fisher-gatherers, relying entirely on wild foods.

The raw materials were presumably imported because Poverty Point is located in a rockless environment and stone was needed for tools and other items. The nearest sources of "local" chert gravels are more than $40 \mathrm{~km}$ distant from the site (Ford and Webb 1956), but they could have been obtained directly. The extensive amount of distant foreign material found at Poverty Point is presumed to be the product of a sophisticated trade or exchange network, the exact nature of which is unclear (Gibson 1994, 1999). Also unclear is the extent to which exotic raw materials found at other sites of the Poverty Point culture were obtained through independent means or through redistribution as a result of 
Poverty Point and culturally related sites will require a better understanding of the source locations, the spatial patterns of raw material distribution, and temporal variation in artifact types.

83 Copper is a relatively rare material ( $n=188$ objects) in the enormous Poverty Point artifact assemblage, and it is reported to occur in only two culturally related sites, Cedarland and Claiborne, located on the Gulf Coast at the mouth of the Pearl River (Gibson 1994). Most of the copper artifacts are nonutilitarian in nature and thus their spatial and temporal distributions are not governed by functional requirements. If the ages of excavated copper specimens can be delimited, changes in the exchange and redistribution network might be discerned (cf. Gibson 1973) and conclusions may be drawn about community interactions. In addition, a Lake Superior source, if true, extends the territory of the exchange network northward considerably, and decreases the efficiency of acquisition, as no other exotic materials are currently identified as coming from that region. Other potential geological sources, including glacial drift copper of the Midwest and southern Appalachian copper, could be coincident with other raw materials, and the efficiency of acquisition, by having multiple materials at the same source and at a lesser distance, would increase.

\subsection{Native Copper Sources and Sourcing in Eastern North America}

Copper artifacts are often found in archaeological sites dating to the last three to four millennia in eastern North America. Archaeologists often assume that much or most of this copper originated from the extensive native copper deposits found in the vicinity of Lake Superior (e.g. Carr 2005; Fogel 1963; Griffin 1961; Walthall et al. 1982). Lake Superior hosts the largest native copper deposits in the world (Rapp 2000) and the distribution of copper in eastern North America is not inconsistent with a Lake Superior origin (Fogel 1963; Goad 1978, 1980), leading to a widespread and often uncritical acceptance of this assumption.

However, a more critical and empirical examination of copper materials is necessary to determine sources prior to the construction of explanatory models preferencing distant access or modes of acquisition. Using the trace-element composition of copper artifacts to identify likely sources has great potential and a long history beginning with basic assay techniques around the turn of the $20^{\text {th }}$ Century (Moore 1903). Scientists turned to more sophisticated methods by the 1950 s when efforts using spectrographic analysis of copper artifacts from the Mississippian Etowah site demonstrated an Appalachian source for the raw material (Hurst and Larson 1958). Additional successes accompanied increasing methodological sophistication in the late $20^{\text {th }}$ and early $21^{\text {st }}$ centuries (e.g. Goad 1978, 1980; Goad and Noakes 1978; Levine 1996; Rapp 1980, 1990), aided greatly by the decades of research performed by Rapp and colleagues (Rapp 1990, Rapp et al. 1980; Rapp et al. 2000). The appearance of new and more sensitive mass spectrometry methods (Cooper et al. 2008; Hill 2012a, 2012b; Lattanzi 2008, 2013; Levine 2007a, 2007b; McKnight 2008) has produced even greater understanding of prehistoric copper acquisition. These studies of native copper composition have demonstrated that 2012a, 2012b; Lattanzi 2013; Levine 1996, 2007a; McKnight 2008), should not be assumed. 


\subsection{Copper Sources}

120 In the early $19^{\text {th }}$ century, geologists rediscovered the extensive native copper deposits in the region around Lake Superior and noted the extensive prehistoric mining of this resource on Isle Royale and the Keweenaw Peninsula (Foster and Whitney 1859; Martin 1999; Whittlesey 1863; Winchell 1881). This brought the Lake Superior region into prominence as a widely known source of prehistoric native copper.

125

126

127

128

129

130

131

132

133

134

135

136

137

138

139

140

141

142

143

144

145

146

147

148

149

150

151

152

153

154

However, other sources of native copper are found in eastern North America, most notably in the Appalachian Mountains and the Canadian Maritimes, and have been known for some time (e.g. Ross 1935; Watson 1923; Wherry 1910). The geological processes that created these deposits are distinctly different from those around Lake Superior, and may be expected to lead to differential elemental composition.

As noted by Rapp and colleagues (2009; 2000:96), provenance studies must carefully define the scope of potential geological sources. For this study, those sources are initially kept quite broad and defined most simply by two distinct geological events including a) the volcanism associated with the formation of the midcontinent rift system in the Great Lakes, and b) the collision of tectonic plates that formed the Appalachian chain. Additional definitions will then further divide these source areas into smaller units that maximize internal homogeneity of geological and geographical variability.

\subsubsection{Lake Superior sources}

Native copper in the Lake Superior basin of the upper Great Lakes region is the result of Precambrianaged volcanism and rifting associated with the formation of the Midcontinental Rift System beginning approximately 1.1 billion years ago (Bornhorst 1997; Hollings et al. 2007; Martin 1999; Rapp et al. 2000). An upwelling mantle plume formed a hotspot under the continental crust, creating a volcanic dome and weak spot that led to a rapidly spreading rift system (Hollings et al. 2007; Hutchinson et al. 1990; Nicholson and Shirey 1990). Magma rose upward into this spreading rift creating the mafic and ultramafic deposits of the Keweenawan basalts through which volatile gases rose, forming vesicles often subsequently filled with minerals carried in solution such as copper, silver, and calcite.

The Lake Superior copper deposits were largely produced by 1.05 billion years ago (Bornhorst 1997). Today, they outcrop along the edges of the now-collapsed volcanic dome, which form the highlands of the Keweenaw Peninsula, the North Shore of Minnesota and Ontario, and the large islands of Isle Royale and Michipicoten Island (Martin 1999; Rapp et al. 2000). Pleistocene glaciers crossed these outcrops, eroding copper from bedrock deposits and depositing it in the glacial till as far south as Illinois, Indiana, and Ohio (Halsey 2004).

\subsubsection{Sources in the Appalachians and Canadian Maritimes}

The geological origins of copper in the Appalachians and Canadian Maritimes regions differ significantly from that of the Lake Superior region. While the latter was the result of volcanism, the bedrock of the Appalachians and Maritimes was formed through collision events between the African and North 
American tectonic plates as well as the accretion of a number of independent terranes (Hatcher 1989; Williams 1995).

The southern and central Appalachians include the eastern edge of the Laurentide plate that was impacted by the African plate during the Paleozoic period, millions of years after the rifting event that created the Lake Superior sources to the west (Hatcher 1989:2-4). Native copper is associated with the main Blue Ridge outcrop belt from Pennsylvania to central Virginia, and a second belt in the Piedmont of Virginia and North Carolina (Rapp et al. 2000:13-15). These generally late Precambrian- and Cambrianaged rocks are known to contain copper in both native and mineral forms, particularly in locations such as Gold Hill, North Carolina, and in southern Pennsylvania (Rapp et al. 2000). Copper sources have been documented throughout the Appalachians (Ross 1935), in Virginia (Dietrich 1970), North Carolina (Wilson and McKenzie 1978), Pennsylvania (Gordon 1922; Stose 1910, 1932), Tennessee and northern Georgia (Hurst and Larson 1954), New Jersey (Lattanzi 2013; Woodward 1944), and north into New England (Dana 1887; Shepard 1837; Weed 1911).

To the north, the Canadian Maritimes are a complex mix of North American continental materials of the northern Appalachian region and terranes that originated as fragments of continental plates and that currently form portions of New England and the Maritimes (Williams 1995). Ophiolites, or uplifted oceanic mafic crust, also outcrop in the Maritimes, brought to the surface again by the Appalachian orogen but with somewhat different geological origins. Copper here has been noted in Labrador (Evans 1952), Newfoundland, and Nova Scotia (Rapp et al. 2000). Copper bearing deposits in the northern Appalachian orogen and Canadian Maritimes have been correlated with similar deposits in the southern Appalachians (Gair and Slack 1980).

As a result, copper in the Appalachians and the Maritimes, unlike that from the Lake Superior region, is the product of a complex series of Paleozoic events and sources which occurred as the African and North American tectonic plates collided. At the macro scale of this analysis, southern and central Appalachian copper, including the Pennsylvanian sources and Gold Hill in North Carolina, can be thought of as deriving from an internally consistent source and series of events. Copper from the Maritimes includes the Cap d'Or source in Nova Scotia, associated with accreted terranes, and the Trout River source on the western shore of Newfoundland, associated with the miogeocline of the Canadian Appalachian region (Williams 1995).

The central and southern Appalachians, Nova Scotia, and Newfoundland are thus treated as three similar by separable subregions of an eastern macro-region in this study. Yet it should be remembered that copper sources in each of these subregions derive from the geological processes of the Appalachian orogen, and may well show elemental similarities throughout the macro-region that are distinct from those derived from the quite different and much earlier geological processes of the Lake Superior region.

\section{Methods}

Six samples of copper materials from Poverty Point (Table 1) were compared with the compositional profiles of 62 copper source samples representing sources in the Great Lakes, Appalachians, and 
Canadian Maritimes. The Poverty Point samples were selected from existing collections housed at the Poverty Point Curatorial Facility and represent approximately three percent of the known copper from the site. As is the case with much Poverty Point copper, these samples are poorly provenienced. However, as this was an initial "test of concept" study, the sample was deemed sufficient to provide a tentative analysis of copper provenance.

Table 1. Poverty Point copper samples.

\begin{tabular}{llllc}
\hline Provenience/Catalog Information & Collector & & Form & Weight (g) \\
\hline GC-1 & 16WC5-XU3, E20 S15, FS \#3366 & Haag & Bead & 0.84 \\
GC-2 & Lasley Sample 1, South Ridge & Gibson & Flat sheet fragment & 0.27 \\
GC-3 & Lasley Sample 6 & Gibson & Flat sheet fragment & 0.18 \\
GC-4 & 16 WC5-68/CU/9 & Alexander & Nugget & 0.25 \\
GC-5 & $16 W C 5-68 / C U / 10$ & Alexander & Rolled sheet (tube) fragment & 0.32 \\
GC-6 & 16 WC5-68/CU/11 & Alexander & Rolled sheet (tube) fragment & 0.52 \\
\hline
\end{tabular}

Source samples (Table 2) were obtained from the extensive copper collection developed by George Rapp (see Rapp et al. 2000 for additional details) and currently housed at Michigan Technological University. A total of 62 samples, representing sources around Lake Superior, Nova Scotia, Newfoundland, and the central to southern Appalachians were used in this analysis (Figure 1).

Table 2. Source samples.

\begin{tabular}{lllc}
\hline Macro Region & Site/Source & State/Province & No of Samples \\
\hline Maritimes & Cap d'Or & Nova Scotia & 3 \\
Maritimes & Trout River & Newfoundland & 4 \\
Appalachians & Cornwall & Pennsylvania & 1 \\
Appalachians & & Pennsylvania & 5 \\
Appalachians & Greenstone & Pennsylvania & 2 \\
Appalachians & Gold Hill & North Carolina & 1 \\
& & & \\
Lake Superior & Michipicoten & Ontario & 6 \\
Lake Superior & Quincy Mine & Michigan & 1 \\
Lake Superior & Minesota Mine & Michigan & 5 \\
Lake Superior & Centennial Mine & Michigan & 6 \\
Lake Superior & Champion Mine & Michigan & 10 \\
Lake Superior & Minong Mine/Isle Royale & Michigan & 8 \\
Lake Superior & Snake River & Minnesota & 10 \\
\hline
\end{tabular}

These 62 source and 6 Poverty Point samples were analyzed at the Institute for Integrated Research in Materials, Environment and Society (IIRMES) at California State University Long Beach. LA-ICP-MS uses a laser to first pre-ablate (remove contaminants and/or corrosion products on the surface) and then vaporize a sample that is subsequently introduced into the ICP Mass Spectrometer for analysis. Accordingly, no drilling, dissolution or other sample preparation is required; the only trace of the 
211 analysis is an almost imperceptibly tiny mark that looks like a clean spot on the artifact at the point

212 where the sample was taken. This method was selected due to its proven effectiveness, sensitivity and

213 the relatively small area of damage caused by the laser ablation (Cooper et al. 2008; Speakman et al.

214 2002).

215 LA-ICP-MS analysis was performed on the samples using a New Wave Research UP-213 laser ablation

216 system coupled with both a GBC Optimass time-of-flight and an Agilent 4500 quadripole mass

217 spectrometer. Three standards were used for data calibration: SRM 1107 Naval Brass, SRM 500

218 Unalloyed Copper, and SRM 1110 Red Brass.

219 While one of the strengths of LA-ICP-MS is that it allows for microscopic sampling of artifacts, and thus

220

221

222

223

224

225

226

227

228

229

230

231

232

233

234

can be applied to museum specimens with little adverse effect on the appearance of the artifact, this also poses a potential analytical problem. Copper artifacts are not internally homogenous and elemental composition can vary from one location to another on a sample. Unlike bulk techniques that test the composition of an entire artifact, LA-ICP-MS analyzes the composition of discrete locations. To compensate for this variability, four spots were analyzed on each of the six Poverty Point artifacts, and the average of the four analyses was then used as the elemental signature. An earlier analysis was performed with the raw un-averaged data with substantially the same result (Hill et al. 2010)

Elemental concentrations were measured in parts per million (ppm) and the means and standard deviations of the four separate readings were calculated based on the raw data for each of the six Poverty Point copper samples. These data, and the data from the 62 source samples, were then transformed to enhance normality using a power transformation as described previously (for a more detailed description of the transformation, see Hill 2012a:110-113, 2012b; Rapp et al. 2000:63-64). The resulting data were then analyzed using discriminant function analysis (Baxter 1994; Shennan 1997:350352) to calculate the probabilities that the Poverty Point copper samples are compositionally consistent with either Lake Superior or eastern sources.

\section{Results}

Mass spectrometry of the six Poverty Point samples produced usable data for thirteen elements in parts per million (Table 3). Means and standard deviations for each artifact were calculated and then transformed using the power transformation outlined in Hill (2012a:113). The source sample data were collected previously using the same methods (Hill 2012a).

Multiple discriminant function analyses were performed on these data by varying the number of different source regions used as the grouping variable. Using only the elemental composition data, discriminant function analysis attempts to recreate assigned groups, and determines the success rate of doing so, providing a measure of the degree to which elemental composition discriminates between these sources. Also using only the compositional data, discriminant function analysis will determine the most likely associations of unknown samples, such as the Poverty Point copper examined here, among the available source groups. 
Three different groupings of sources were examined: a simple two source-region study comparing combined Lake Superior sources with combined eastern sources of the Appalachians and Maritimes; a three source-region study comparing combined Lake Superior sources with Appalachian sources and a separate grouping of Maritime sources; and a four source-region study which examined combined Lake Superior sources (Isle Royale, Michipicoten Island, Keweenaw Peninsula, and Snake River) with separate Maritime sources (Cap d'Or in Nova Scotia and Trout River in Newfoundland) and Appalachian sources.

Table 3. Elemental composition data for each of the Poverty Point copper samples (PPM)

\begin{tabular}{|c|c|c|c|c|c|c|c|c|c|c|c|c|c|}
\hline Sample & $\mathrm{Al}$ & $\mathrm{Fe}$ & $\mathbf{N i}$ & $\mathrm{Cu}$ & $\mathrm{Zn}$ & As & $\mathrm{Ag}$ & Cd & In & Sn & $\mathrm{Sb}$ & $\mathrm{Au}$ & $\mathrm{Pb}$ \\
\hline GC-1.D & 11.5 & 124.5 & 0.0 & 998961.0 & 136.7 & 284.2 & 11.0 & 0.0 & 0.0 & 2.2 & 5.1 & 0.0 & 150.0 \\
\hline GC-1-2.D & 17.5 & 213.8 & 16.2 & 999130.0 & 82.6 & 242.6 & 14.0 & 0.0 & 0.0 & 0.6 & 2.3 & 0.0 & 28.3 \\
\hline GC-1-3.D & 15.1 & 48.9 & 51.2 & 999369.2 & 39.6 & 174.4 & 46.4 & 0.0 & 0.0 & 2.9 & 9.2 & 0.0 & 30.9 \\
\hline GC-1-4.D & 25.3 & 75.2 & 0.0 & 999185.9 & 142.1 & 244.5 & 23.6 & 0.0 & 0.0 & 2.9 & 7.4 & 0.0 & 48.4 \\
\hline GC-2.D & 8.3 & 93.0 & 22.6 & 999786.9 & 21.3 & & 0.0 & 6.6 & 0.0 & 13.7 & 0.0 & & 19.0 \\
\hline GC-2-2.D & 9.3 & 48.2 & 0.0 & 999907.5 & 0.0 & & 0.0 & 0.8 & 0.0 & 0.0 & & & 18.6 \\
\hline GC-2-3.D & 7.9 & 0.0 & 6.9 & 999900.2 & 0.0 & 0.0 & 6.6 & 0.0 & 0.0 & 0.0 & 2.5 & 1.4 & 58.4 \\
\hline GC-2-4.D & 10.7 & 194.1 & 34.1 & 999635.8 & 0.0 & 42.5 & 0.0 & 0.0 & 0.0 & 3.1 & 3.7 & 0.0 & 9.3 \\
\hline GC-3.D & 10.7 & 7.6 & 0.0 & 999746.7 & 77.1 & 6.4 & 49.3 & 13.5 & 0.0 & 6.0 & & 1.7 & 4.3 \\
\hline GC-3-2.D & 9.3 & 136.9 & 4.6 & 999709.7 & 12.9 & 0.0 & 65.1 & 4.7 & 0.0 & 1.7 & 2.5 & 0.0 & 1.4 \\
\hline GC-3-3.D & 2.6 & 119.7 & 0.0 & 999725.9 & 40.6 & 46.0 & 42.3 & 0.0 & 0.0 & 0.0 & 3.3 & 1.3 & 0.0 \\
\hline GC-3-4.D & 48.4 & 30.2 & 33.5 & 999660.9 & 6.3 & 8.4 & 32.1 & 0.0 & 0.0 & 3.0 & 4.8 & 0.5 & 7.8 \\
\hline GC-4.D & 60.2 & 422.9 & 14.3 & 997708.9 & 114.7 & 111.4 & 47.5 & 0.0 & 0.0 & 0.0 & 1.0 & 2.2 & 1230.5 \\
\hline GC-4-2.D & 46.4 & 486.0 & 49.0 & 997794.9 & 124.6 & 131.7 & 22.0 & 2.8 & 0.0 & 4.8 & 1.4 & 0.0 & 1094.2 \\
\hline GC-4-3.D & 20.5 & 8.1 & 70.6 & 997861.7 & 118.0 & 169.4 & 29.1 & 0.0 & 0.0 & 2. 5 & 0.0 & 0.0 & 1539.8 \\
\hline GC-4-4.D & 81.7 & 398.1 & 88.5 & 997197.6 & 190.0 & 190.7 & 43.1 & 0.0 & 0.0 & 0.0 & 7.2 & 0.0 & 1500.5 \\
\hline GC-5.D & 10.8 & 170.5 & 0.0 & 991714.7 & 0.0 & 60.8 & 163.3 & 4. 8 & 0.0 & 3.4 & 0.0 & 1.9 & 7785.9 \\
\hline GC-5-2.D & 11.2 & 189.9 & 5.8 & 990997.6 & 0.0 & 28.8 & 190.1 & 11.0 & 0.0 & 13.5 & 2.1 & 0.0 & 8474.7 \\
\hline GC-5-3.D & 60.8 & 82.1 & 54.8 & 998654.5 & 0.0 & 0.0 & 241.2 & 0.0 & 0.0 & 1.0 & 9.9 & 2.2 & 875.1 \\
\hline GC-5-4.D & 19.4 & 0.0 & 0.0 & 992635.5 & 16.4 & 72.3 & 213.1 & 0.0 & 0.0 & 4.7 & 12.5 & 0.0 & 6940.0 \\
\hline GC-6.D & 25.2 & 213.2 & 0.0 & 995770.6 & 144.7 & 63.7 & 119.7 & 7.5 & 0.0 & 3.0 & 1.6 & 0.0 & 3478.6 \\
\hline GC-6-2.D & 9.6 & 147.8 & 49.3 & 999235.8 & 80.4 & 0.0 & 179.7 & 4.6 & 0.0 & 8.1 & 0.0 & 0.0 & 252.2 \\
\hline GC-6-3.D & 19.9 & 392.6 & 63.2 & 997946.8 & 76.7 & 67.6 & 224.7 & 0.0 & 0.0 & 4.1 & 9.8 & 3.1 & 1089.4 \\
\hline GC-6-4.D & 28.0 & 85.1 & 40.5 & 999362.4 & 0.0 & 40.5 & 296.5 & 0.0 & 0.0 & 9.5 & 1.5 & 7.2 & 35.0 \\
\hline
\end{tabular}
The first analysis simply divided the source areas into the two broad macro regions of 1) Lake Superior sources and 2) eastern sources composed of the Appalachians and their northern extension into the

257 Maritimes. This test produced the highest reclassification success rate of any of the analyses, with 85.5 258 percent of the originally grouped cases correctly classified (Wilks' Lambda=0.618; $p=.011$ ). Most of the 259 Lake Superior sources (91.3\%) were correctly classified, while 31.3 percent of the eastern sources were 260 misclassified as Lake Superior sources, suggesting that any provenance errors are more likely to falsely 261 indicate a Lake Superior source rather than falsely indicate an eastern source.

262 In this simple test, the elemental composition of all six Poverty Point copper artifacts is most consistent 263 with the eastern sources (Table 4). The probabilities that Poverty Point copper was most consistent with 264 the eastern macro region ranged from 0.73 to 0.97 (Figure 4a).A second test was conducted using three 
source groups, including 1) the Lake Superior macro region, 2) the central and southern Appalachians, and 3 ) the Maritimes. This produced a somewhat lower reclassification success rate in which 82.3 percent of the originally grouped cases were correctly classified (Wilks' Lambda=0.392; $p=.001$ ). The greatest source of misclassification was the incorrect assignment of some samples of Maritimes copper to Lake Superior sources (14.3\%) and vice versa (13.0\%). All Appalachian copper was correctly identified as such.

Table 4. Discriminant function analysis classification results, two macro region test.

\begin{tabular}{lcc}
\hline Source Location & Poverty Point Artifact Predicted Source \\
& $N$ & $\%$ \\
\hline Lake Superior & 0 & 0 \\
Eastern Sources & 6 & 100.0 \\
\hline
\end{tabular}

In this test, four of the six Poverty Point samples were found most similar to sources in the Maritimes, while two were compositionally consistent with the Appalachians (Table 5). As in the previous twosource test, none of the Poverty Point samples were found to be most consistent with the Lake Superior macro region. Probabilities for the Maritimes associated samples ranged from 0.56 to 0.80 , while the Appalachian sources were associated with probabilities of 0.68 and 0.69 (Figure 4b).

Table 5. Discriminant function analysis classification results, three macro region test.

\begin{tabular}{lcc}
\hline Source Location & Poverty Point Artifact Predicted Source \\
& $N$ & $\%$ \\
\hline Lake Superior & 0 & 0 \\
Appalachians & 2 & 33.3 \\
Maritimes & 4 & 66.7 \\
\hline
\end{tabular}

The third test divided source areas into four source macro-regions, including 1) the Lake Superior macroregion, 2) the combined central and southern Appalachians, 3) Nova Scotia, and 4) Newfoundland. This test also resulted in a reclassification rate of 82.3 percent (Wilks' Lambda $=0.302 ; p \leq .003$ ). Errors in reclassification occurred when Lake Superior sources were incorrectly identified as Appalachian $(n=3)$, Nova Scotian $(n=4)$, or from sources in Newfoundland $(n=2)$. Less frequently, Appalachian sources were incorrectly identified only once when one sample was erroneously identified as Nova Scotian in origin, while one sample from Nova Scotia was incorrectly attributed to Lake Superior.

All six of the Poverty Point copper samples were assigned to sources in Nova Scotia (Table 6, Figures 2 and 3). Three of the artifacts exhibited their second highest source probabilities in the Lake Superior region while the remaining three showed their second highest probabilities in the Appalachians, though the Lake Superior probabilities were quite low (Figure 4c). 
Table 6. Discriminant function analysis classification results, four macro region test.

\begin{tabular}{lcc}
\hline Source Location & \multicolumn{2}{c}{ Poverty Point Artifact Predicted Source } \\
& $N$ & $\%$ \\
\hline Lake Superior & 0 & 0 \\
Appalachians & 0 & 0 \\
Nova Scotia & 6 & 100.0 \\
Newfoundland & 0 & 0 \\
\hline
\end{tabular}

\section{Conclusions and Directions for Future Research}

Of the six Poverty Point copper artifacts examined in this study, none were consistent with the chemical composition of sources in the Great Lakes in any of the three tests. Instead, the composition of these artifacts associates them most closely with sources in eastern North America, primarily in the Appalachian Mountains and Nova Scotia. While this represents a small sample of the Poverty Point copper assemblage, these artifacts indicate that at least some of the copper at Poverty Point may derive from geological sources in the east.

Although eastern provenances are indicated for the Poverty Point copper samples tested here, the paucity of available data from sources of native copper in the Appalachians and Maritimes suggests that the exact geological sources of Poverty Point copper remain unknown. However, these results indicate that the sources of Poverty Point copper are likely to be found in the Appalachian region. Even the surprising similarities with copper sources of Nova Scotia are logically consistent with potential unsampled areas in the Appalachians. Such similarity may likely derive from shared geological processes associated with the Appalachian orogen rather than actual procurement of copper from the Maritimes. As with the geology of Nova Scotia, the southern Appalachians were also formed through the accretion of terranes and the impact of the African and Laurentide tectonic plates during the early Paleozoic. The problems presented by this underlying geological similarity are exacerbated in this study by the poorly sampled nature of Appalachian sources, particularly those in the southern Appalachians and adjacent Piedmont, potentially leading to the similarities seen here between Poverty Point copper and sources in the Maritimes. In particular, similarities with Nova Scotia sources may direct attention to the unsampled southern Appalachian terranes as a potential source. Of course, at this point, the Maritimes cannot be ruled out as a copper source in models of Poverty Point exchange, but this would require substantial revision of our understanding of eastern Late Archaic economies. Rapp and colleagues (2000:96) have noted the importance of carefully delineating the area of interest for this very reason.

The results demonstrate that researchers cannot assume that copper at Poverty Point derived from sources in the Great Lakes even with the construction of logically consistent arguments. In this case, the use of lead isotope composition for Poverty Point galena demonstrated the use of sources in both the Ozark Plateau and farther north in the Upper Mississippi Valley (Ghosh 2008; Walthall et al. 1982). The presence of Upper Mississippi galena fits with an established narrative that Poverty Point exchange materials often originated in the Mississippi, Ohio, and tributary valleys (Gibson 1994), with an implicit suggestion of transport to Poverty Point along those rivers. In this context, the proximity of the Upper 


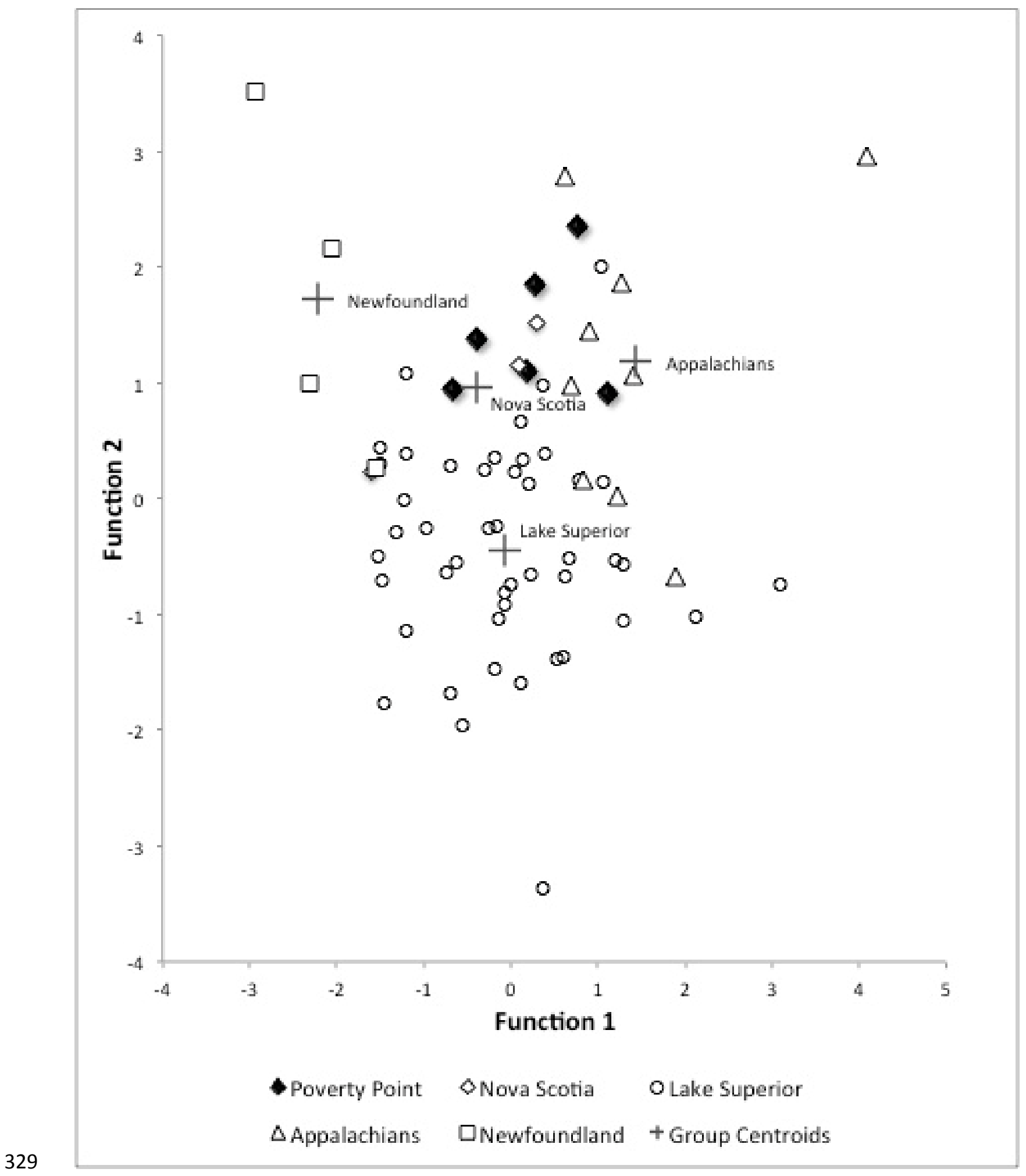

Figure 2. Plot of Discriminant function scores for functions 1 and 2, four-source test. 


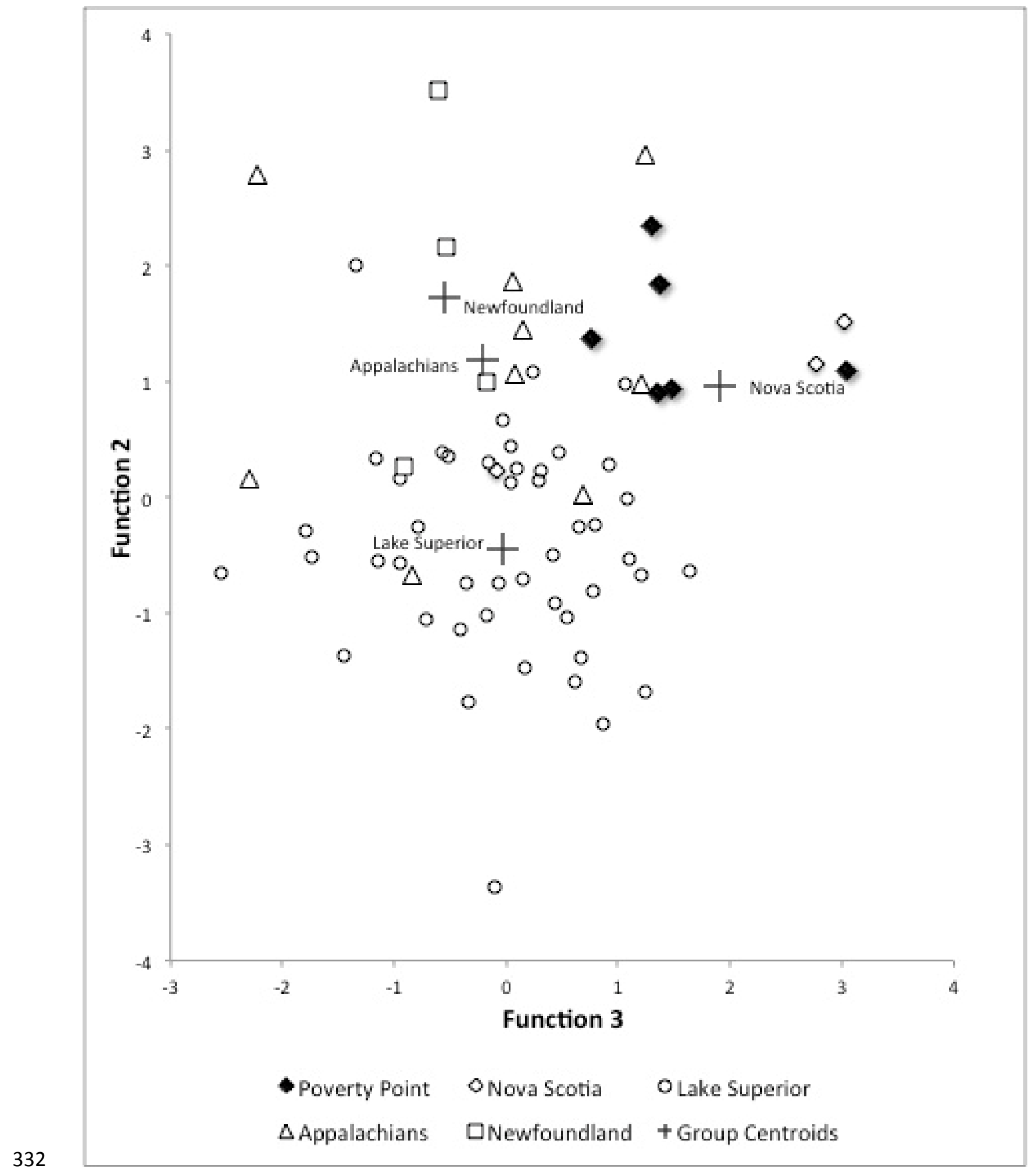




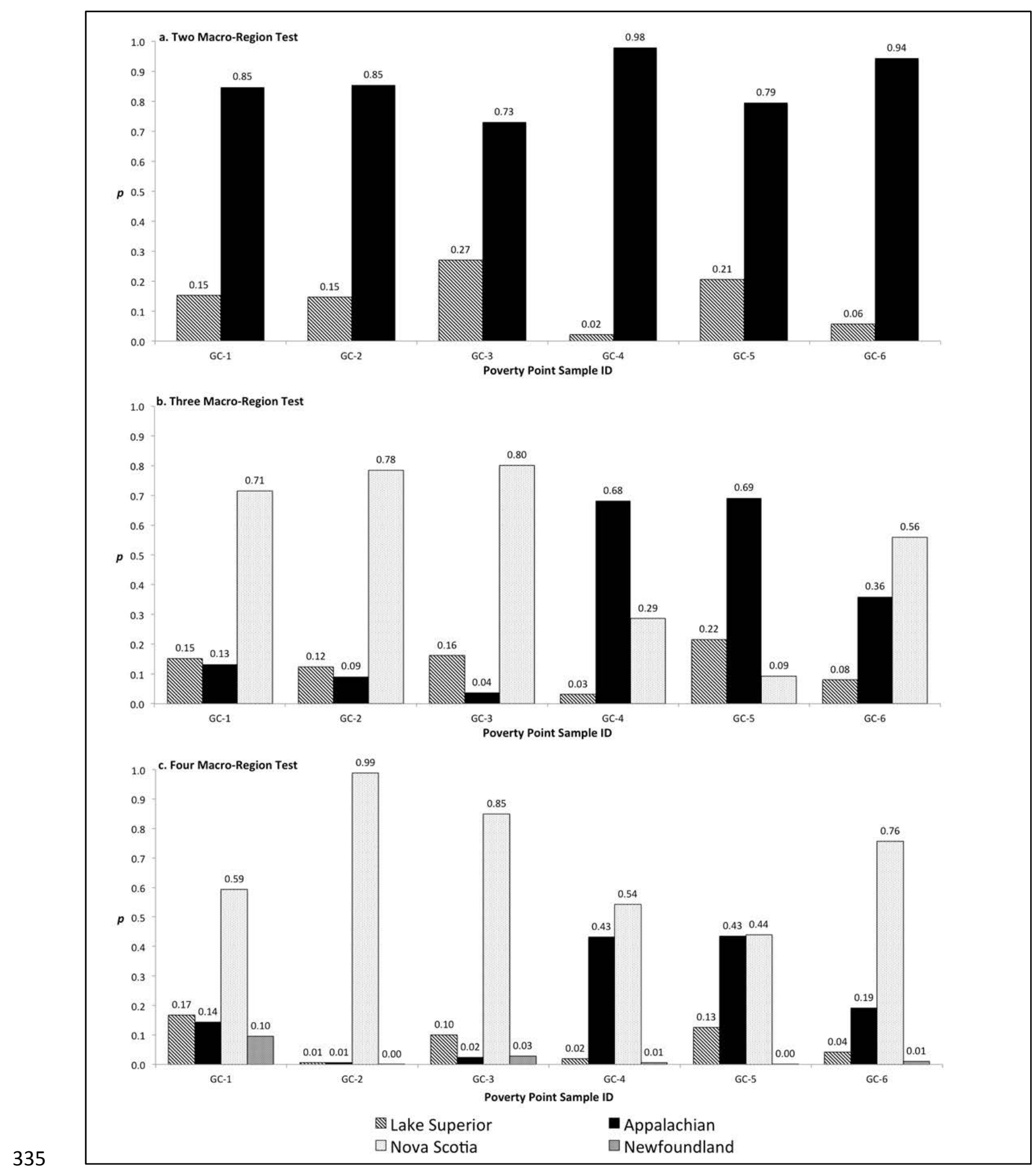

Figure 4. Source probabilities for the two, three, and four macro-region tests. 
Mississippi River with the copper deposits of Lake Superior, along with the known presence of native copper in the glacial till of the Upper Mississippi Valley (Halsey 2004), suggests a logical conclusion that copper may also have followed this pathway to the south.

However, it would be equally logical to argue the copper followed pathways of steatite transport from the southern Appalachians to Poverty Point (Truncer 2004; Yates 2009), as these steatite sources are equally coincident with copper sources in the Appalachians (Rapp 2000; Watson 1923). The lack of direct river access from these locations to Poverty Point appears not to have hampered the movement of steatite across the southeast to the Lower Mississippi Valley based on the large numbers of steatite bowl fragments at Poverty Point (Truncer 2004). Indeed, most of the materials imported to Poverty Point originated in the southeast and the northern galena source is a distinct northern outlier (Figure 1).

Using LA-ICP-MS, this study shows that at least some of the copper at Poverty Point is more consistent with eastern sources than those of the Great Lakes region. While copper may indeed have made the long trip down the Mississippi River, as Gibson (2001) suggests, none of the six artifacts tested here showed any affinity to Great Lakes sources. Instead, it is worth considering the possibility that the copper artifacts are consistent with the majority of exotic Poverty Point materials in having their origins in the southern and eastern portions of North America. As Goad (1978) observed with regard to Archaic and Woodland copper in the southeast, and Walthall and colleagues (1982:139-141) noted with regard to galena, diachronic analysis of copper source utilization may show further patterns that indicate changing use of source regions and shifting networks of social interactions affiliated with the Poverty Point culture of the Lower Mississippi Valley, yet the small sample size examined here prevents such analysis.

Clearly, additional analyses are critical to understanding the nature of copper acquisition and redistribution. A reduced geographic range would be in keeping with a recent reanalysis of obsidian found at the surface at Poverty Point and once believed to represent a westward extension of the acquisition network into the Rockies of Wyoming (Gibson 2001, 2010); it is now known to be a contaminant from Glass Buttes, Oregon, and almost certainly a product of modern flintknappers at the site (Greenlee et al. 2014). If future work reveals that the copper came from southern Appalachian locations that were coincident with other materials found at Poverty Point, like steatite and schist, this would suggest that the acquisition network was less extensive, and more intensive, than previously believed. The presence of copper at Claiborne and Cedarland would be consistent with a coastal transport pathway from the southern Appalachians to Poverty Point, and that could have implications for the direction of redistribution.

\subsection{Suggestions for Future Research}

We must acknowledge the preliminary nature of this study. Only six copper samples from Poverty Point were analyzed here (3.2 percent of the currently known total), and while the sample of Great Lakes copper source materials is quite large, far fewer samples of Appalachian sources were available for 
analysis. Another shortcoming of this study is the inability to examine diachronic patterns in source utilization.

377 Future research into Poverty Point copper sourcing should attempt to resolve these two shortcomings 378 by first procuring additional samples from native copper sources in the southern Appalachians. Future 379 analysis may also benefit from an examination of lead isotope ratios as they have shown promise in 380 copper studies elsewhere in North America, although these isotopes have also been found to be difficult to detect at useful levels (Cooper et al. 2008). It may be expected that given a larger sample size of such

382 sources and an examination of isotope ratios, the association of Nova Scotia sources may be found to be 383 a product of sample limitations. If Nova Scotia continues to be well represented in Poverty Point copper 384 sources even after an exhaustive sampling of southern Appalachian copper, models of Poverty Point 385 exchange and eastern Archaic economies will need to be reassessed.

386 Secondly, additional samples of copper artifacts from Poverty Point may indeed show more complexity 387 in copper sourcing than demonstrated here. The current study cannot rule out the use of Lake Superior 388 copper at Poverty Point, rather it can only demonstrate that there is little indication of such source 389 utilization in the samples examined here. However, additional analyses may yet reveal more complex 390 patterns of copper procurement associated with social or temporal factors as has been demonstrated in 391 other copper source studies (e.g. Goad 1978; Hill 2012a; Lattanzi 2008, 2013; Levine 1996, 2007;

392 McKnight 2007). An understanding of the dynamic contexts of copper procurement in this important 393 community is to be desired.

\section{Acknowledgements}

396 The authors wish to thank the Louisiana Office of State Parks for their loan of copper artifacts for this 397 analysis, Michigan Technological University for their loan of copper source samples, and the National 398 Science Foundation grant (BCS-0917702) supporting the operation of the IIRMES Laboratory at California 399 State University Long Beach. 


\section{References}

Baxter, Michael J.

1994 Exploratory Multivariate Analysis in Archaeology. Edinburgh University Press, Edinburgh. Bell, Robert E.

1956 A Copper Plummet from Poverty Point, Louisiana. American Antiquity 22(1):80.

Bornhorst, Theodore J.

1997 Tectonic Contexts of Native Copper Deposits of the North American Midcontinent Rift System. In Middle Proterozoic to Cambrian Rifting, Central North America, pp. 127-136, edited by R.W. Ojakangas, A.B. Dickas, and J.C. Green. Geological Society of America, Special Paper No. 312. Boulder, Colorado.

\section{Carr, Christopher}

2005 Rethinking Interregional Hopewellian "Interaction." In Gathering Hopewell: Society, Ritual, and Ritual Interaction, pp. 575-623, edited by C. Carr and D.T. Case. Kluwer Academic/Plenum Publishers, New York.

Connolly, Robert P.

2006 An Assessment of Radiocarbon Age Results from the Poverty Point Site. Louisiana Archaeology 27:1-14.

Cooper, H. Kory, M. John M. Duke, Antonio Simonetti, and GuangCheng Chen

2008 Trace element and $\mathrm{Pb}$ isotope provenance analyses of native copper in northwestern North America: results of a recent pilot study using INAA, ICP-MS, and LA-MC-ICP-MS. Journal of Archaeological Science 35:1732-1747.

Dana, James D.

1887 Manual of Mineralogy and Petrography (fourth edition). John Wiley, New York.

Dietrich, R.V.

1970 Minerals of Virginia. Research Division Bulletin 47, Virginia Polytechnic Institute, Blacksburg, Virginia.

Evans, E.L.

1952 Native Copper Discoveries in the Seal Lake Area, Labrador. Proceedings of the Geological Association of Canada 5:11-116.

Fogel, Ira L.

1963 The Dispersal of Copper Artifacts in the Late Archaic Period of Prehistoric North America. The Wisconsin Archeologist 44(3):129-180.

Ford, James A. and Clarence H. Webb 1956 Poverty Point, A Late Archaic Site in Louisiana. Anthropological Papers of the American Museum of Natural History, Volume 46, Part 1. New York.

Foster, John W. and Josiah D. Whitney 1850 Report on the Geology and Topography of a Portion of the Lake Superior Land District in the State of Michigan. Part I: Copper Lands. U.S. House $31^{\text {st }}$ Congress, $1^{\text {st }}$ Session, House Document 69. 
Gair, Jacob E., and John F. Slack

1980 Stratabound Massive Sulphide Deposits of the U.S. Appalachians. In Review of Caledoian-

Appalachian Stratabound Sulphides, pp67-81. Geological Survey of Ireland Special Paper 5

Ghosh, Sanghamitra

2008 Heavy Stable Isotope Investigations in Environmental Science and Archeology. Unpublished

Ph.D. dissertation, Department of Earth, Ocean and Atmospheric Sciences, Florida State University, Tallahassee.

Gibson, Jon L.

1994 Empirical Characterization of Exchange Systems in Lower Mississippi Valley Prehistory. In Prehistoric Exchange Systems in North America, edited by Timothy G. Baugh and Jonathan E. Ericson, pp. 127-175. Plenum Press, New York.

1999 Swamp Exchange and the Walled Mart: Poverty Point's Rock Business. In Raw Materials and Exchange in the Mid-South, edited by Evan Peacock and Samuel O. Brookes, pp. 57-63.

Proceedings of the $16^{\text {th }}$ Annual Mid-South Archaeological Conference, Archaeological Report No. 29. Mississippi Department of Archives and History, Jackson, Mississippi.

2001 The Ancient Mounds of Poverty Point: Place of Rings. University Press of Florida, Gainesville, Florida.

2007 "Formed From the Earth at that Place": The Material Side of Community at Poverty Point. American Antiquity 72:509-523.

2010 Poverty Point Redux. In Archaeology of Louisiana, pp. 77-96, edited by M. Rees. Louisiana State University Press, Baton Rouge, Louisiana.

Glascock, Michael D.

2002 Obsidian Provenance Research in the Americas. Accounts of Chemical Research 35:611-617 Goad, Sharon I.

1978 Exchange Networks in the Prehistoric Southeastern United States. Unpublished Ph.D. dissertation, Department of Anthropology, University of Georgia.

1980 Chemical Analysis of Native Copper Artifacts from the Southeastern United States. Current Anthropology 21(2):270-271.

Goad, Sharon, and John Noakes

1978 Prehistoric Copper Artifacts in the Eastern United States. Archaeological Chemistry II, pp. 335-346. American Chemical Society.

Gordon, S.G.

1922 The Mineralogy of Pennsy/vania. Special Publication 1, the Academy of Natural Sciences of Philadelphia, Philadelphia Pennsylvania.

Greenlee, Diana M.

20092009 Annual Report of the Station Archaeology Program at Poverty Point State Historic Site. Unpublished report submitted to the Division of Archaeology, Louisiana Office of Cultural Development, Baton Rouge. Department of Geosciences, University of Louisiana at Monroe, Monroe.

20112011 Annual Report of the Station Archaeology Program at Poverty Point State Historic Site. Unpublished report submitted to the U.S. National Park Service. Department of Atmospheric Science, Earth Science and Physics, University of Louisiana at Monroe, Monroe. 
Greenlee, Diana M., Richard E. Hughes, and Thomas M. Origer 2014 Poverty Point's Obsidian. Louisiana Archaeology 37:89-107. Griffin , James B.

1961 Lake Superior Copper and the Indians: Miscellaneous Studies of Great Lakes Prehistory. Anthropological Papers of the Museum of Anthropology. University of Michigan, Ann Arbor. Halsey, John R. 2004 Copper from the Drift. Revised and expanded version of a paper presented at the 50th Midwest Archaeological Conference and the 61st Southeastern Archaeological Conference. St. Louis, MO. Unpublished manuscript on file in the Poverty Point Curation Facility, Epps, LA. Hargrave, Michael, R. Berle Clay, Rinita Dalan and Lewis Somers 2010 Magnetic Gradient, Susceptibility, and Resistance Surveys at Poverty Point. Paper presented at the $75^{\text {th }}$ Anniversary Meeting of the Society for American Archaeology, St. Louis/ Hatcher, Robert D.

1989 Appalachians Introduction. In: The Appalachian-Ouachita Orogen in the United States, edited by Hatcher, R.D., W.A. Thomas, and G.W Viele, pp. 1-6. The Geological Society of America, vol. F-2. Boulder, Colorado.

Hill, Mark A.

2012a The Benefit of the Gift: Exchange, Ritual, and Emergent Regional Systems in the Late Archaic Western Great Lakes. International Monographs in Prehistory series. Ann Arbor, Michigan 2012b Tracing Social Interaction: Perspectives on Archaic Copper Exchange from the Upper Great Lakes. American Antiquity 77(2):279-292.

Hill, Mark A., Diana M. Greenlee, and Hector Neff 2010 Sourcing Poverty Point Copper: Testing the Lake Superior Hypothesis. Paper presented at the Symposium entitled Current Research on the Poverty Point Culture. $75^{\text {th }}$ Annual Meeting of the Society for American Archaeology. St. Louis, Missouri.

Hollings, Pete, Phillip Fralick, and Brian Cousens 2007 Early History of the Midcontinent Rift Inferred from Geochemistry and Sedimentology of the Mesoproterozoic Osler Group, Northwestern Ontario. Canadian Journal of Earth Sciences, 44(3): 389-412.

Horton, J.W., Drake, A.A., and Rankin, D.W.

1989 Tectonostratigraphic Terranes and their Paleozoic Boundaries in the Central and Southern Appalachians. Geological Society of America Special Paper 230:213-245.

Hurst, Vernon J. and Lewis H. Larson Jr. 1958 On the Source of Copper at the Etowah Site, Georgia. American Antiquity 24(2):177-181 Hutchinson, D.R., R.S. White, W.F. Cannon, and K.J. Schulz 1990 Keweenaw Hot Spot: Geophysical Evidence for a 1.1 Ga Mantle Plume beneath the Midcontinent Rift System. Journal of Geophysical Research: Solid Earth 95(B7):10869-10884. Lasley, Scott E. 1983 Particle Induced X-ray Emission (PIXE) Analysis of Trade Items from Poverty Point, Louisiana. Honors Thesis, University of Southwestern Louisiana, Lafayette. 
Lattanzi, Gregory D.

2008 Elucidating the Origin of Middle Atlantic Pre-contact Copper Artifacts Using Laser Ablation ICP-MS. North American Archaeologist 29:297-326

2013 The Value of Reciprocity: Copper, Exchange, and Social Interaction in the Middle Atlantic Region of the Eastern Woodlands of North America. Unpublished Ph.D. dissertation, Department of Anthropology, Temple University. Philadelphia, Pennsylvania.

Levine, Mary Ann

1996 Native Copper, Hunter-gatherers, and Northeastern Prehistory. Unpublished Ph.D. dissertation, University of Massachusetts, Amherst, Massachusets. 2007a 'Determining the provenance of native copper artifacts from northeastern North America: Evidence from instrumental neutron activation analysis." Journal of archaeological science 34(4): 572-587.

2007b Overcoming Disciplinary Solitude: The Archaeology and Geology of Native Copper in Eastern North America. Geoarchaeology Vol. 22(1):49-66

Martin, Susan R. 1999 Wonderful Power: The Story of Ancient Copper Working in the Lake Superior Basin. Wayne State University Press, Detroit.

McKnight, Matthew D.

2007 The Copper Cache in Early and Middle Woodland North America. Unpublished Ph.D.

Dissertation, Department of Anthropology, The Pennsylvania State University, College Station. Moore, Clarence B.

1903 Sheet Copper from the Mounds is Not Necessarily of European Origin. American Anthropologist 5:27-48.

Nicholson, Suzanne W., and Steven B. Shirey 1990 Midcontinent Rift Volcanism in the Lake Superior Region: Sr, Nd, and Pb Isotopic Evidence for a Mantle Plume Origin. Journal of Geophysical Research: Solid Earth 95(B7):10851-10868 Rapp, George 2009 Archaeomineralogy. Springer Science and Business Media, New York. Rapp, George Jr. 1990 Native Copper Sources of Artifact Copper in Pre-Columbian North America. In: Archaeological Geology of North America, edited by N. P. Lasca and J. Donohue, pp. 479498. Geological Society of America, Centennial Special Volume 4, Boulder, Colorado.

Rapp, George Jr., James Allert, Vanda Vitali, Zhichun Jing, and Eiler Henrickson 2000 Determining Geologic Sources of Artifact Copper. University Press of America, Lanham, Maryland.

Rapp, George Jr., Eiler Henrickson, Michael Miller, and Stanley Aschenbrenner 1980 Trace-Element Fingerprinting as a Guide to the Geographic Sources of Native Copper. Journal of Metals 32(1):35-45.

Ross, Clarence S. 1935 Copper Deposits in the Eastern United States. In Copper Resources of the World, pp. 151166. vol. 1., XVI International Geological Congress, Washington. 
Sassaman, Kenneth E.

$$
2005 \text { Poverty Point as Structure, Event, Process. Journal of Archaeological Method and Theory }
$$
12(4):335-364.

Shackley, M. Steven 1995 Sources of Archaeological Obsidian in the Greater American Southwest: An Update and Quantitative Analysis. American Antiquity 60(3): 531-551.

1998 Gamma Rays, X-Rays and Stone Tools: Some Recent Advances in Archaeological Geochemistry. Journal of Archaeological Science 25: 259-270.

2002 More than Exchange: Pre-Ceramic through Ceramic Period Obsidian Studies in the Greater North American Southwest. In Geochemical Evidence for Long Distance Evidence for Long-Distance Exchange, edited by M.D. Glaskcock, pp. 53-87. Bergin and Garvey, Westport, Connecticut.

Shennan, Stephen

1997 Quantifying Archaeology. University of lowa Press, lowa City.

Shepard, C.U.

1837 Report on the Geological Survey of Connecticut. B.L. Hamlen, New Haven, Connecticut. Smith, Brent W. 1991 The Late Archaic-Poverty Point Trade Network. Geoscience \& Man 29:173-180.

Speakman, Robert J., Hector Neff, Michael Glascock, and Barry Higgins

2002 Characterization of Archaeological Materials by Laser Ablation-Inductively Coupled Plasma-Mass Spectrometry. In Archaeological Chemistry: Materials, Methods, and Meanings, edited by K.A. Jakes, pp. 48-63. American Chemical Society, Washington D.C.

Stose, George W. 1910 The Copper Deposits of South Mountain in Southern Pennsylvania. Bulletin of the United States Geological Survey 430:122-131.

1932 Geology and Mineral Resources of Adams Co. Pennsylvania. Pennsylvania Geological Survey, Fourth Series, County Reports C1.

Truncer, James 2004 Steatite Vessel Age and Occurrence in Temperate Eastern North America. American Antiquity 69(3):487-513

Tykot, Robert $\mathrm{H}$.

2003 Determining the Source of Lithic Artifacts and Reconstructing Trade in the Ancient World. In Written in Stone: The Multiple Dimensions of Lithic Analysis, edited by P.N. Kardulis and R.W. Yerkes, pp. 59-85. Lexington Books, Lanham, Maryland.

Walthall, John A., Clarence H. Webb, Stephen H. Stow and Sharon I. Goad 1982 Galena Analysis and Poverty Point Trade. Midcontinental Journal of Archaeology 7:133-148. Watson, T.L.

1923 Native Copper Deposits of the South Atlantic States Compared with those of Michigan. Economic Geology 18:732-752.

Webb, Clarence $\mathrm{H}$. 1968 The Extent and Content of Poverty Point Culture. American Antiquity 33(3):297-321. 1982 The Poverty Point Culture (second edition). Geoscience and Man 17. 
611 Weed, Walter $\mathrm{H}$.

6121911 Copper Deposits in the Appalachian States. Pennsylvania Geological Survey, Fourth Series,

613 County Reports C1.

614 Whittlesey, Charles C.

6151863 Ancient Mining on the Shores of Lake Superior. Smithsonian Contributions to Knowledge

616 13(4):1-32.

617 Williams, Harold

6181995 Geology of the Appalachian-Caledonian Orogen in Canada and Greenland. Geology of

619 Canada, no. 6. Geological Survey of Canada, Ottawa.

620 Wilson, W.F., and B.J. McKenzie

6211978 Mineral Collecting Sites in North Carolina. Information Circular 24, North Carolina

622 Geological Survey, Raleigh, North Carolina.

623 Winchell, N. H.

6241981 Ancient Copper-Mines of Isle Royale. Popular Science Monthly 19(5):601-620.

625 Wisseman, Sarah, Thomas Emerson, and Randall E. Hughes

6262010 Preliminary Report on Mineralogical Analyses of Southeastern Steatite. Unpublished report

627

628

629

630

631

632

633 on file with the Poverty Point Station Archaeology Program, Epps, LA.

Woodward, Herbert P.

1944 Copper Mines and Mining in New Jersey. Bulletin 57, Geological Series, Department of Conservation and Development, State of New Jersey, Trenton.

Yates, Wm. Brian

634

635

636 